\title{
SPATIAL AND TEMPORAL COMPARISONS OF GOPHER ROCKFISH (SEBASTES CARNATUS) LIFE HISTORY AND CONDITION IN SOUTH CENTRAL CALIFORNIA
}

\author{
A Thesis \\ presented to \\ the Faculty of California Polytechnic State University, \\ San Luis Obispo
}

\author{
In Partial Fulfillment \\ Of the Requirements for the Degree \\ Master of Science in Biology
}

by

Natasha Leigh Meyers-Cherry

December 2014 
(C) 2014

Natasha Leigh Meyers-Cherry

ALL RIGHTS RESERVED 


\section{COMMITTEE MEMBERSHIP}

TITLE:

Spatial and temporal comparisons of gopher rockfish (Sebastes carnatus) life history and condition in south central California

AUTHOR: $\quad$ Natasha Leigh Meyers-Cherry

DATE SUBMITTED: December 4, 2014

COMMITTEE CHAIR: $\quad$ Royden Nakamura, PhD

Professor of Biological Sciences

COMMITTEE MEMBER: Dean Wendt, PhD

Professor of Biological Sciences

COMMITTEE MEMBER: Benjamin Ruttenberg, PhD

Assistant Professor of Biological Sciences 


\begin{abstract}
Spatial and temporal comparisons of gopher rockfish (Sebastes carnatus) life history and condition in south central California Natasha Leigh Meyers-Cherry
\end{abstract}

Recent studies have shown environmental factors influence life history traits in fishes. Understanding intraspecific variability of life history characteristics and condition is necessary to determine local fisheries management strategies. Gopher rockfish, Sebastes carnatus, comprise $50 \%$ of the estimated shallow nearshore recreational rockfish catch in California, yet insufficient local data exist regarding life history traits and condition of this species. Our study locally defines growth parameters, size (age) at reproductive maturity, and condition for gopher rockfish in south central California. The growth parameter values of gopher rockfish from our study are similar to previously published research. However, our data also indicate that the current local gopher rockfish stock in south central California reaches reproductive maturity at a larger size and an older age when compared to gopher rockfish sampled throughout central California (primarily in Monterey) between 1977-1982. Furthermore, we examined spatial and temporal differences of life history information, within and outside of two south central California Marine Protected Areas (MPAs) established in 2007 , between two time periods. Our data show that the size and longevity of fish has increased after the establishment of MPAs.

Keywords: Life history, Sebastes carnatus, Marine Protected Areas 


\section{ACKNOWLEDGMENTS}

This research was supported by a California Sea Grant Traineeship, The David and Lucile Packard Foundation, The Resources Legacy Fund Foundation, the California Coastal Conservancy, the California Ocean Protection Council, the Montgomery and Richards Marine Biology Scholarship, the Tenera Environmental Scholarship, and the Aryan I. Roest Memorial Scholarship. Thank you to Royden Nakamura, Dean Wendt, and Benjamin Ruttenberg for all of your wisdom and guidance. Thanks to the captains and deckhands associated with Patriot Sportfishing and Virg's Landing, as well as the dedicated volunteer anglers who contributed to this project. Thank you to Erin Loury for donating otoliths from her previous studies, and to Meisha Key at the NMFS, Santa Cruz for providing me those samples. I'd also like to thank Don Pearson at the NMFS, Santa Cruz and Katherine Schmidt at Moss Landing Marine Laboratories for their experience aging rockfish. In addition, thanks to Grant Waltz, Lisa Needles, Carolyn Ewers, Morgan Ivens-Duran, Melissa Daugherty, Lenora Brewer, Cate Webster, Heather Price, Eric Anderson, Paul Carvalho, Lesley Stein, Nate Hall, Lindsay Faye, Kristen Byron, Megan Wilson, Brian Zelenke, Cal Poly Scientific divers, and the faculty, staff, and students of the Biological Sciences department for their contributions. A huge thank you to my husband, Matthew Preston, for providing me unwavering support throughout this process. And very special thanks to the gopher rockfish that were sacrificed to make this study possible! 
LIST OF TABLES..........................................................vii

LIST OF FIGURES ..............................................viii

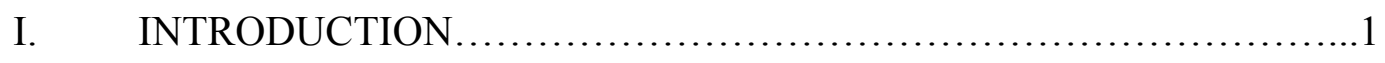

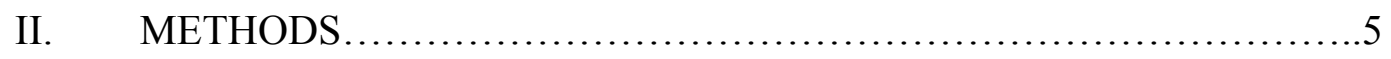

$1 \quad$ Experimental Methods........................................... 5

$1.1 \quad$ Sampling Protocols.....................................6

1.2 Aging: otolith analysis.................................

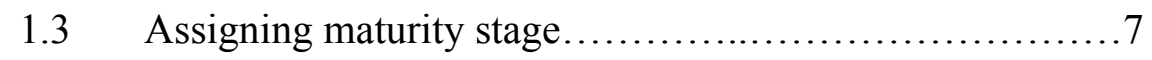

$1.4 \quad$ Calculating condition.................................. 9

$2 \quad$ Analyses.................................................. 9

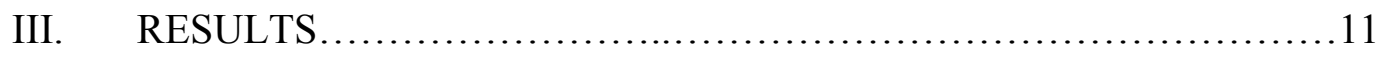

$1 \quad$ Growth parameter estimates....................................11

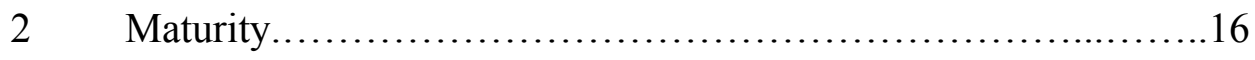

3 Condition................................................ 17

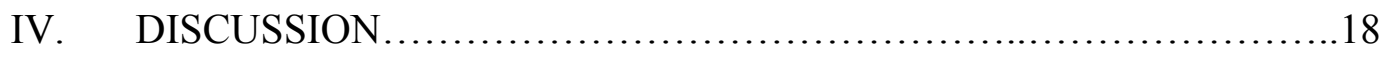

$1 \quad$ Growth parameter estimates................................... 18

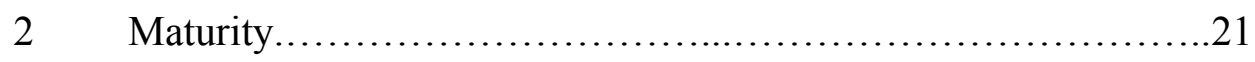

3 Condition...................................................... 22

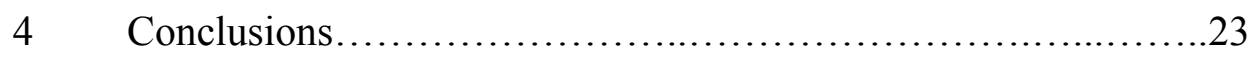

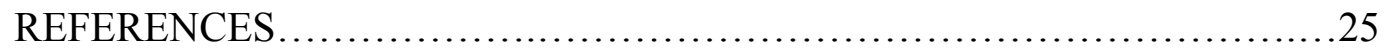




\section{LIST OF TABLES}

Page

Table

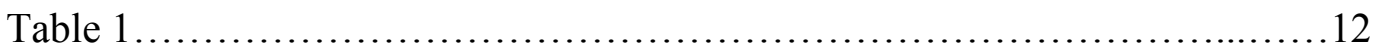




\section{LIST OF FIGURES}

Page

Figure

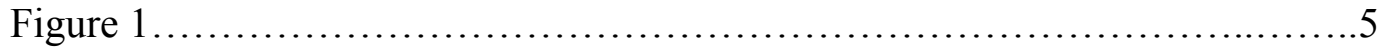

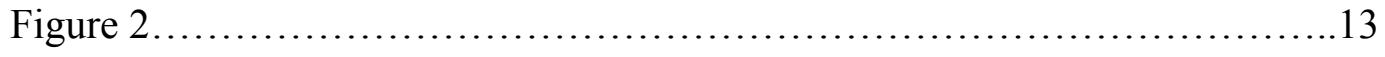

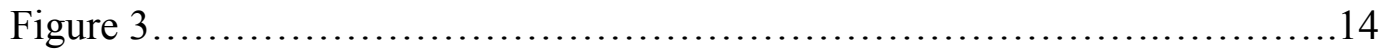

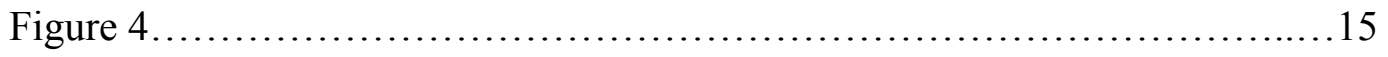

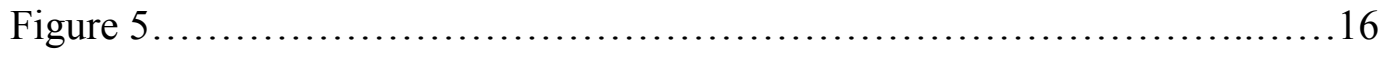




\section{INTRODUCTION}

It is well understood that natural and anthropogenic factors affect the physiological condition of individuals and hence the populations they compose. Naturally occurring environmental factors may influence life history traits in fishes (Reznick et al. 1990; Ruttenberg et al. 2005; Hamilton et al. 2007; Caselle et al. 2011). Furthermore, anthropogenic factors like fishing (Rijnsdorp 1993; Rochet 1998; Law 2000; Conover 2007) can also alter these characteristics. Understanding regional variation in life history characteristics and fish condition due to multifarious environmental influences among geographically distinct locations can improve current fisheries management strategies.

Life history traits including growth parameters and maturity calculations are critical to determine appropriate fisheries management efforts; they can be used as indicators to predict species and population-level vulnerability (Adams 1980; Roff 1984; Stokes et al. 1993; Reynolds et al. 2005), and to determine localized management strategies (Caselle et al. 2011) in the form of harvest restrictions for economically valuable species. Allowable harvest rates should be calculated based on life history data from local populations so that Biological Reference Points (BRP) for stock biomass, growth, maturity, recruitment, and mortality are regionally accurate. Using this knowledge, Target Reference Points (TRP) can be set for local populations that aptly promote the long-term sustainable exploitation of stocks. This kind of information is especially valuable for long-lived, slow growing species that maximize reproductive output at larger sizes (older ages) that may be vulnerable to overharvesting (Adams 1980). 
Understanding life history growth parameters $\left(L_{\infty}\right.$ and $\left.T_{\max }\right)$ and determining the size (age) at which individuals and populations attain reproductive maturity is relevant to fisheries management because of the reproductive implications of having larger (older) fishes in populations. "The Big Old Fat Fecund Female Fish" (BOFFFF) hypothesis states that larger fish are more fecund and may produce higher quality offspring than smaller individuals in certain species (Berkeley et al. 2004, Palumbi 2004, O'Farrell and Botsford 2005, Sogard et al. 2008). Therefore, allowing fish to reach larger maximum sizes and older ages amplifies their reproductive output. For this reason, preserving old growth fish is essential to the stability and future productivity of fisheries systems (Hixon et al. 2013). Understanding regional variability of growth parameters as well as size (age) at sexual maturity allows management strategies to account for intraspecific differences among local populations.

In addition to life history information, assessing variability in fish condition over time and space can also be useful to inform fisheries management. Hepatosomatic index (HSI) is often utilized to represent indirect measures of energy reserves in fish, and can be used to assess the overall health of fish populations (Bolger and Connolly 1989). Larger hepatosomatic indices often indicate healthier fish in better energetic condition (Bolger and Connolly 1989). Past research indicates that fish with lower measures of condition are less productive (Rätz and Lloret. 2003).

Rockfish belong to the genus Sebastes, and are an economically valuable group of fishes that primarily exist in the Northeast Pacific (Love et al. 2002). 
They are long-lived, slow growing, late maturing, have episodically irregular recruitment patterns, and possess small home ranges (Love et al. 2002).

Furthermore, commercial fishing efforts have reduced populations (Karpov et al. 1995; Love et al. 1998; Mason 1998), and several management strategies have been implemented for Sebastes species (Leaman 1991; Parker et al. 2000; Love et al. 2002). For this study, gopher rockfish Sebastes carnatus (Jordan and Gilbert 1880) was chosen to ascertain regional ecological and fisheries variability. Gopher rockfish range from Oregon to Baja California (Love 2011) and are a shallow water species often targeted by recreational anglers (Chen et al. 2012). They comprise $50 \%$ of estimated shallow nearshore recreational rockfish catch in California (Key et al. 2005); however, limited data exist concerning spatial and temporal variability in key life history characteristics or condition of this species. The first and only stock assessment for gopher rockfish in 2005 by Key et al. (California Department of Fish and Wildlife and the National Marine Fisheries Service) assumes analogous life history information for all populations of this species, north of Point Conception (in "northern" California) and does not discuss any other distinctions at smaller spatial scales or over time. By making this assumption, some localized populations may be overfished while other populations are being under-utilized. Understanding how life history traits vary across geographical locations accounts for the possibility that populations of fish occupy distinct regions and may require different management strategies. Defining regional life history characteristics allow management of local populations at a more appropriate ecological scale. 
This study primarily aims to locally define growth parameter values (estimated maximum sizes and ages), size (age) at reproductive maturity, and condition values (hepatosomatic index (HSI)) of gopher rockfish in south central California to be compared among broader geographic regions. This study was conducted inside and outside of two south central California Marine Protected Areas (MPAs), thus life history traits and condition were compared between MPAs and adjacent fishable waters, as well as between the study areas (Point Buchon and Piedras Blancas). Regional variability in life history information will be better understood by comparing life history parameters of gopher rockfish over time and across geographic locations. Overall, this study compares life history traits and condition of gopher rockfish temporally and spatially in south central California. 


\section{METHODS}

\section{EXPERIMENTAL METHODS}

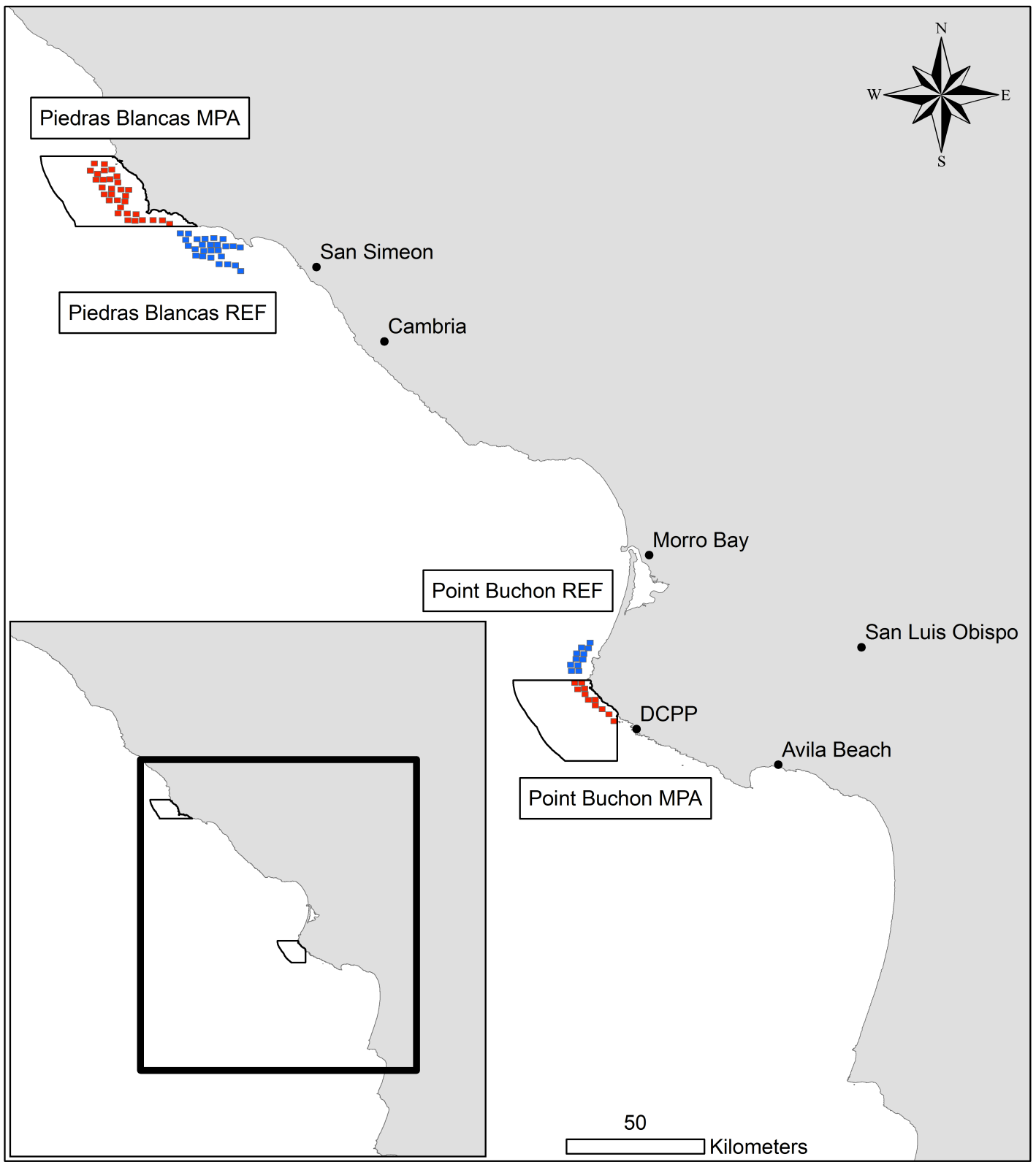

Figure 1. Map of south central California, USA including Point Buchon and

Piedras Blancas State Marine Protected Areas (MPAs) established in 2007, as well as adjacent reference sites (REFs). Data collected mid-July through midSeptember from 2007-2009 and mid-July through mid-November from 2012- 
2013. The Point Buchon and Peidras Blancas MPAs were designed to include shallow rocky reef environments that provide habitats to many nearshore species, including gopher rockfish. Also pictured are key geographical landmarks, including cities for reference. Red marks indicate cells monitored by the CCFRP in the Point Buchon and Piedras Blancas MPAs, while blue marks indicate cells monitored by the CCFRP in the Point Buchon and Piedras Blancas REFs.

\subsection{Sampling protocols}

We collected gopher rockfish opportunistically during the California Collaborative Fisheries Research Program (CCFRP) field seasons from mid-July through mid-September of 2012 and 2013. Among the areas surveyed by the CCFRP, Point Buchon and Piedras Blancas are two large State MPAs, established in 2007 along the south central coast of California. We used standardized hookand-line fishing with baited and unbaited shrimp flies (hooks) and jigs (weighted lures) (Wendt and Starr 2009) to obtain fish within the Point Buchon and Piedras Blancas MPAs as well as in adjacent reference sites (REFs) in south central California, USA (Figure 1). In 2012, we collected fish mid-September through mid-November in the Point Buchon MPA/REF sites, due to an extended sampling season. We collected additional fish in 2013 from mid-September to midNovember on scuba diving surveys in the Point Buchon MPA/REF sites. Furthermore, we collected some samples from licensed recreational fishers on Commercial Passenger Fishing Vessel (CPFV) trips. We recorded individual length to the nearest whole centimeter was; and fish were weighed to the nearest gram. 


\subsection{Aging: otolith analysis}

To estimate the age of fish, we removed sagittal otoliths from sacrificed fish. We weighed and then stored otoliths dry in labeled envelopes. We analyzed additional otoliths collected from a previous study (Loury 2011) between the years 2007-2009.

We aged otoliths using the break-and-burn technique (Chilton and Beamish 1982). To remain consistent through processing, we chose the right otolith from the pair (if available). We snapped otoliths in half along their center (length wise) by placing them sulcus side up between the thumb and forefinger of both hands and carefully applying pressure until fragmented. We toasted the broken surface of the postrostrom half of the otolith (when available) next to a direct flame using fine tip forceps until it turned dark brown in color. Caution was taken to burn both sides of the otolith. After cooling on the table, we embedded the unbroken end of the postrostum in adhesive putty and mounted it on a slide. Then, we brushed vegetable oil onto the broken surface to enhance growth rings and placed it under a dissecting microscope to count visible annuli. A pair of prominent translucent (now browned) and opaque zones was counted as one year of growth in the fish (Lea et al. 1999). We read otoliths blind twice, with at least a week between each reading by a single reader. If there was disagreement in years (a difference of a year or greater), we read samples a $3^{\text {rd }}$ time as per established protocol. 


\subsection{Assigning maturity stage}

We removed and weighed gonads to the nearest $0.001 \mathrm{~g}$. We initially did developmental staging macroscopically. We assigned macroscopic and histological maturity stages for ovaries and testes based on previously published scales (Echeverria 1987, Chilton 2007, and TenBrink and Spencer 2013). Macroscopically, ovaries were determined to be immature if they appeared thin, thread-like, small, translucent, round in shape, and yellow-pink in color. The presence of individual eggs, eyed larvae, or black blotches indicated mature ovaries. We determined testes to be macroscopically immature if they appeared thin, thread-like, small, translucent, and slightly triangular in shape. Mature testes were large, firm, triangular in shape, and white in color. After initial staging, we preserved organs $10 \%$ formalin and had them histologically processed by the Central Coast Pathology lab. One to two gram ovarian and testicular cross sections were embedded in paraffin, thin-sectioned to $4 \mu \mathrm{m}$ using a rotary microtome, mounted on slides, stained with hematoxilyn and eosin, and read under a compound microscope. In each sample, we assessed ovary maturity status by defining the most advanced oocyte stage present. We determined ovaries to be immature if ooginal nests and unyolked oocytes were present. Occasionally, initial yolk accumulation in oocytes with very small yolk globules would also indicate immaturity. The presence of tertiary yolk globules and initial oil vesicles, embryonic "eyed larvae", postovulatory follicles, atretic oocytes, or residual larvae all signified that ovaries were mature. We designated testes to be immature with the presence of germ cells, undifferentiated gonocytes, early to intermediate 
stages of lumen development, or primary to secondary spermatogonia. The existence of developed lumina filled with spermatozoa, sperm ducts filled with spermatozoa, and clustered organizations of spermatocysts indicated mature testes.

\subsection{Calculating condition}

We removed and weighed livers to the nearest $0.1 \mathrm{mg}$. We used hepatosomatic indices (HSI), ratio of liver weight to total body weight, to assess the general conditions of sampled individuals as liver size is relative to the nutritional state of fish (Lambert and Dutil 1997).

\section{ANALYSES}

We used size and age data from the years 2007-2009 and 2012-2013 in analyses. We used non-linear regression models to fit size (total length) at a specific age (years) using the von Bertalanffy growth equation: $L_{t}=L_{\infty}(1-$

$\left.e^{-K\left(t-t_{0}\right)}\right)$ where $L_{t}$ is the length of an individual at age $t, L_{\infty}$ is the theoretical maximum length (asymptotic) individuals were able to grow indefinitely, $K$ is the growth coefficient which is proportional to rate at which $\mathrm{L} \infty$ is reached, $t_{0}$ is the theoretical age at $L=0$ (often negative or zero), and $t$ represents the age of an individual (von Bertalanffy 1934). Since no information existed on the sex of individuals collected from years 2007-2009, we combined sexes for all analyses. For all models, $t_{0}$ was fixed at the value -0.5 (Lea et al. 1999). We related the model parameters $K$ and $L_{\infty}$ across area, site, and over time by calculating zscores from means and SE (standard error) to obtain $p$-values using two-tailed ttests with $95 \%$ confidence intervals. The estimated maximum life span of 
individuals is represented by $T_{\max }$, and is calculated by finding the mean of the upper $25 \%$ of individuals in a given population, based on highest annuli readings (Beverton 1992). Two-sample t-tests using 95\% confidence intervals were used to compare two means, and comparisons were done to see if area, site, or time period is associated with $\left(T_{\max }\right)$. We used Bonferroni corrections when making multiple comparisons.

We modeled size (age) at maturity by using a logistic regression to fit sigmoid curves using the expression $P=\operatorname{Pr}\left(\right.$ Maturity $\left.\mid x_{1}\right)=\left(\frac{e^{\left(b_{0}+b_{1} x_{1}\right)}}{1+e^{\left(b_{0}+b_{1} x_{1}\right)}}\right) . P$ is the probability an individual is mature at length or age $\left(x_{1}\right)$, and the constants $b_{0}$ and $b_{1}$ are parameters that were estimated after fitting the curve. Predicted size (age) at $50 \%$ maturity, the size at which $50 \%$ of fish attain sexual maturity, were estimated with the equation $L(\text { or } A)_{50}=-b_{0} / b_{1}$ using previously estimated constants. We compared $95 \%$ confidence intervals to see if area or site is associated with size (age) at reproductive maturity.

We calculated hepatosomatic index $(\%)$ as $H S I=\left(\frac{L W}{W}\right) \times 100$, where $L W$ is the wet total liver weight (g) of the fish and $W$ is the wet total body weight (g) of the fish. We utilized two-way ANOVAs to test whether the independent variables area or site are associated with $(H S I)$.

We completed statistical analyses using JMP Pro 11 (SAS Institute Inc., Cary, NC). We confirmed normal distributions using Shapiro-Wilk test for Goodness of fit. Parameters for all models are listed as means \pm SE in text and figures, and were reported using $95 \%$ confidence intervals. 


\section{RESULTS}

\section{GROWTH PARAMETER ESTIMATES}

When data from all areas (Point Buchon and Piedras Blancas), sites (MPA and REF), and time periods (2007-2009 and 2012-2013) were combined for gopher rockfish in south central California, the growth parameter $L_{\infty}$ (maximum length) was found to be $34.80 \pm 0.57 ; K$ was $0.18 \pm 0.01$; and $T_{\max }$ (maximum age) was 9.58 years \pm 0.16 .

The estimated growth parameters for fish from the Point Buchon MPA sampled between the years 2012-2013 showed increased maximum length $\left(L_{\infty}\right)$ $(p=0.01)$ and increased $T_{\max }(p<0.0001)$ when compared to individuals sampled in 2007-2009 (Table 1; Figure 2; Figure 3). Increases in $L_{\infty}(p=0.01)$ and $T_{\max }(p=0.001)$ were also seen over time from fish sampled in the Point Buchon REF site in 2012-2013 when compared to fish sampled in 2007-2009. The parameter $T_{\max }$ was significantly higher in the Point Buchon MPA compared to the REF site $(p<0.0001)$ in 2012-2013 (Table 1). Temporal differences in growth parameters were found when data from the Point Buchon MPA and REF sites were combined in years 2007-2009, and then compared to years 2012-2013 (Table 1; Figure 2; Figure 3). Individuals from both sites in years 2012-2013 had significantly higher $L_{\infty}(p=0.002)$ and $T_{\max }(p<0.0001)$ than individuals from 2007-2009.

These temporal differences were also observed in Piedras Blancas when the MPA and REF sites were combined. There was an increase in $L_{\infty}(p=0.038)$ (Table 1; Figure 4; Figure 5) and $T_{\max }(p<0.0001)$ (Table 1) when years 2008- 
2009 were compared to years 2012-2013. Increased $T_{\max }(p=0.0003)$ was also observed over time from fish sampled in the Piedras Blancas REF site in 20122013 when compared to fish sampled in 2007-2009. In addition, the $T_{\max }$ parameter increased $(p<0.0001)$ for fish sampled from the Piedras Blancas MPA in 2008-2009 and compared to the years 2012-2013 (Table 1).

The growth coefficient $(K)$ was identical between area, site, and year (Table 1). No other significant differences were observed in von Bertalanffy growth parameters between areas, sites, or over time $(p>0.05)$.

Table 1. Growth parameters $L_{\infty}, K$, and $T_{\max }$ estimated for all areas (Point Buchon: PB and Piedras Blancas: BL), sites (MPA: M and REF: R), and years. Estimates given in mean \pm standard error (SE).

\begin{tabular}{ccccccc}
\hline Area & Site & Years & Mean $\boldsymbol{L}_{\infty}$ (length) $\pm S E$ & Mean $\boldsymbol{K} \pm S E$ & Mean $\boldsymbol{T}_{\max }$ (years) \pm & $\boldsymbol{N}$ \\
& & & & & $S E$ & \\
\hline BL & M & $08-09$ & $31.06 \pm 1.22$ & $0.24 \pm 0.02$ & $8.07 \pm 0.23$ & 61 \\
BL & R & $08-09$ & $33.05 \pm 1.25$ & $0.22 \pm 0.02$ & $8.80 \pm 0.23$ & 60 \\
BL & M & $12-13$ & $34.86 \pm 1.88$ & $0.18 \pm 0.02$ & $9.92 \pm 0.25$ & 46 \\
BL & R & $12-13$ & $37.19 \pm 1.95$ & $0.17 \pm 0.02$ & $10.10 \pm 0.28$ & 40 \\
PB & M & $07-09$ & $31.81 \pm 0.72$ & $0.25 \pm 0.01$ & $8.84 \pm 0.34$ & 76 \\
PB & R & $07-09$ & $29.16 \pm 0.87$ & $0.35 \pm 0.04$ & $8.07 \pm 0.38$ & 61 \\
PB & M & $12-13$ & $34.38 \pm 0.83$ & $0.22 \pm 0.01$ & $12.40 \pm 0.38$ & 59 \\
PB & $\mathrm{R}$ & $12-13$ & $35.43 \pm 2.11$ & $0.20 \pm 0.03$ & $10.10 \pm 0.46$ & 49 \\
\hline
\end{tabular}




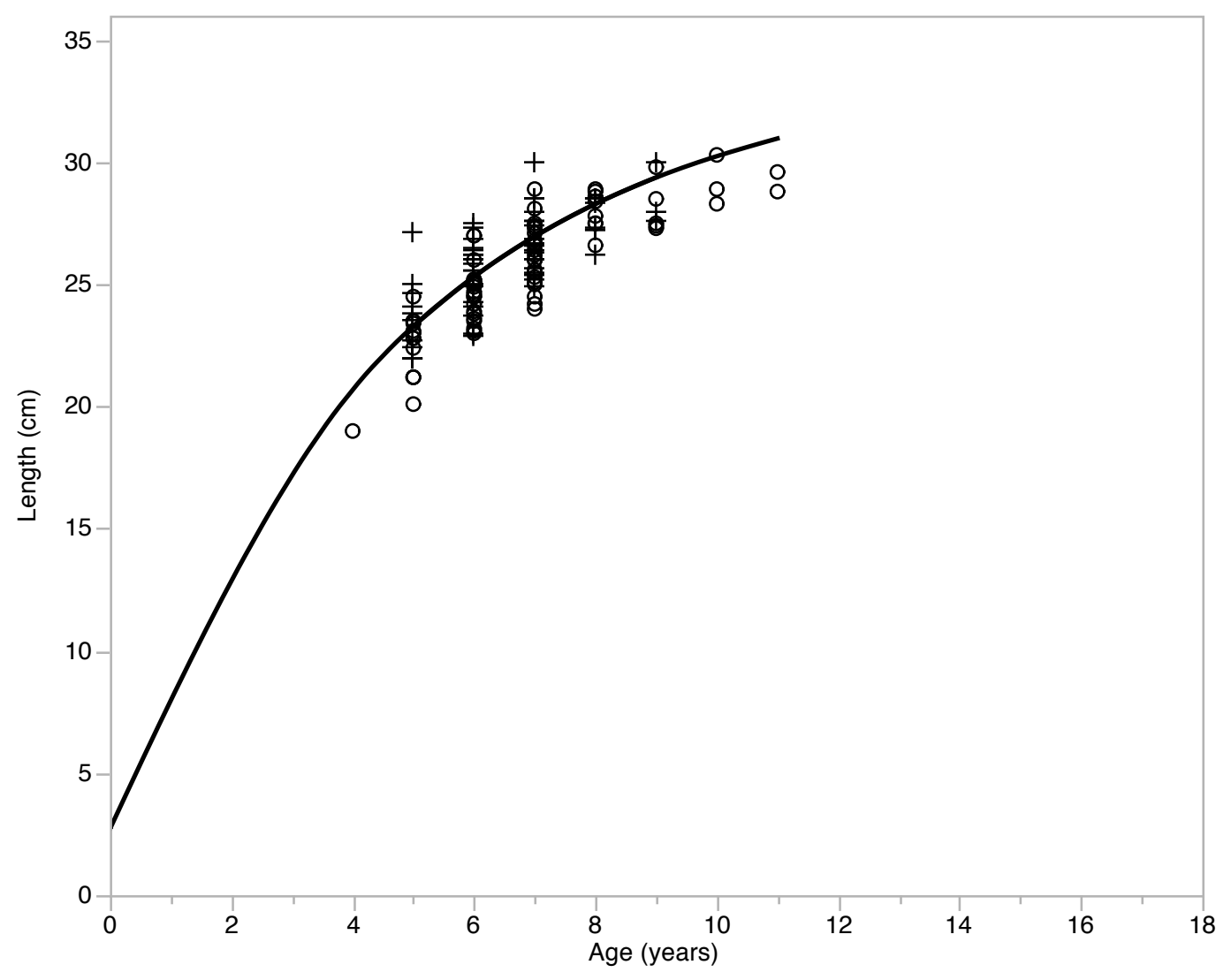

Figure 2. von Bertalanffy growth curve for gopher rockfish sampled in the Point Buchon MPA and REF sites during the 2007-2009 field seasons $(n=136)$. The average $L_{\infty}$ value was $31.27 \mathrm{~cm} \pm 0.60$, and the average $K$ value was $0.27 \pm 0.01$. The value for $t_{0}$ was fixed at -0.5 (Lea et al. 1999). Circles represent data points from the MPA site, and plus symbols represent data points from the REF site. 


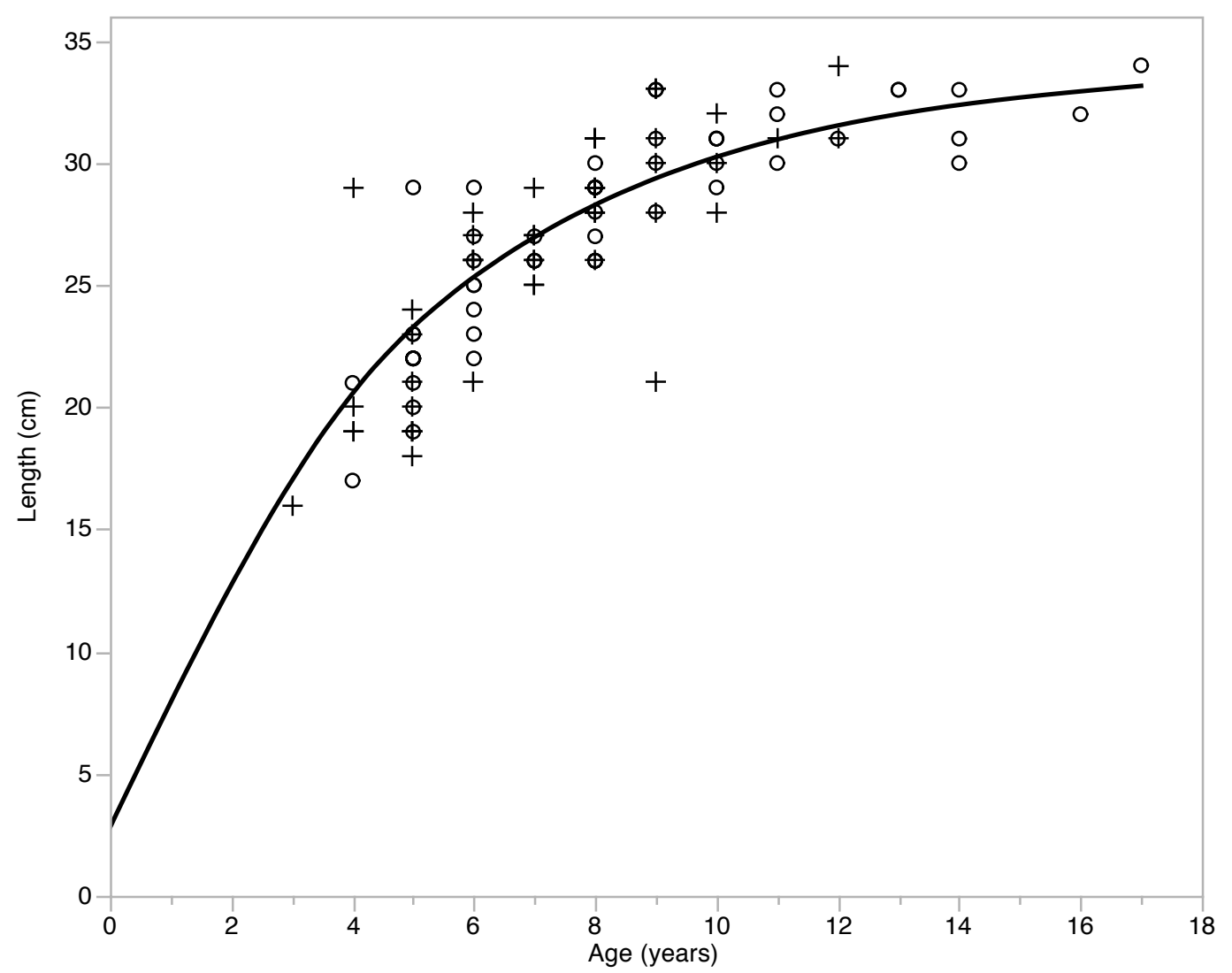

Figure 3. von Bertalanffy growth curve for gopher rockfish sampled in the Point Buchon MPA and REF sites during the 2012-2013 field seasons $(n=108)$. The average $L_{\infty}$ value was $34.65 \mathrm{~cm} \pm 0.88$, and the average $K$ value was $0.21 \pm 0.01$. The value for $t_{0}$ was fixed at -0.5 (Lea et al. 1999). Circles represent data points from the MPA site, and plus symbols represent data points from the REF site. 


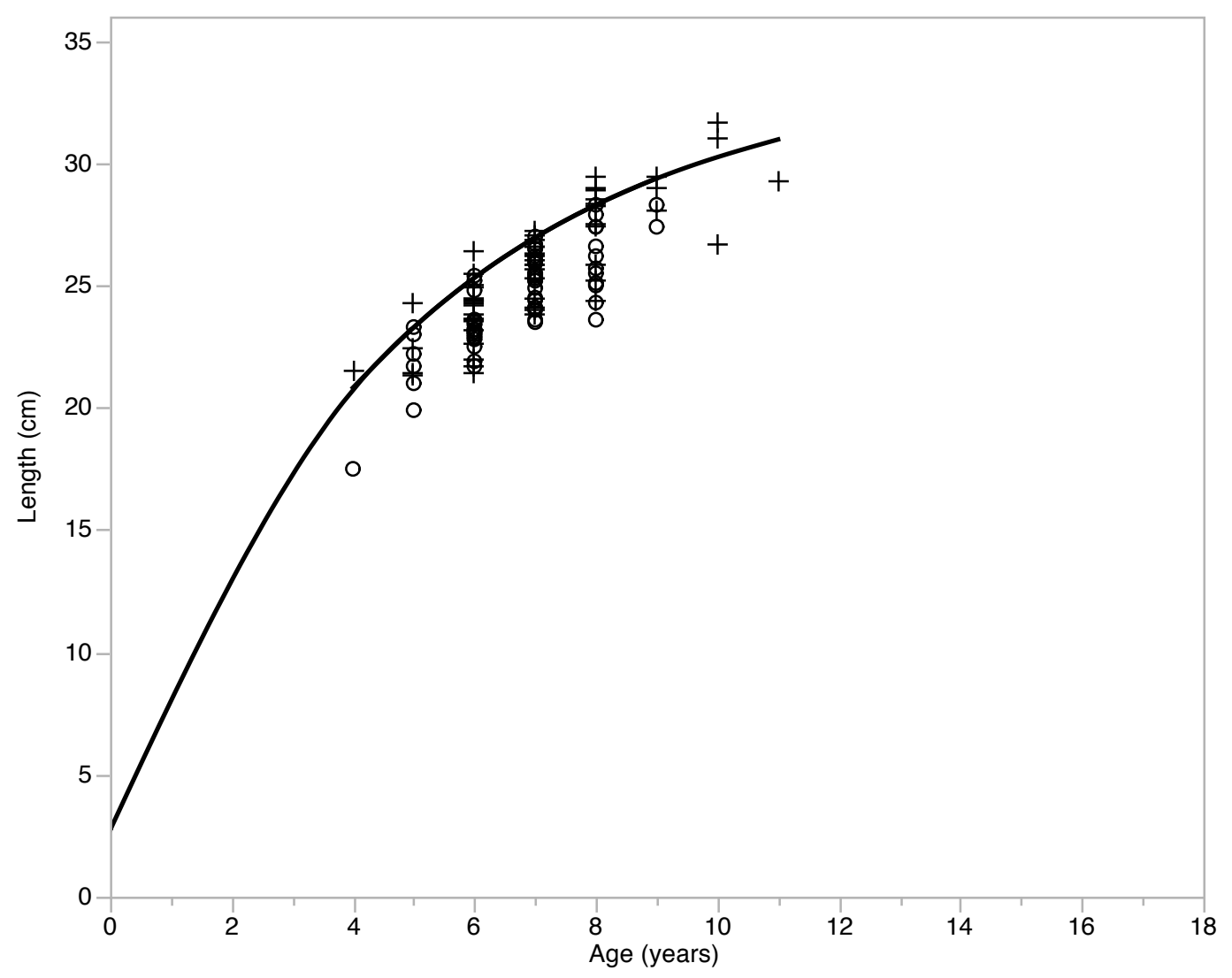

Figure 4. von Bertalanffy growth curve for gopher rockfish sampled in the Piedras Blancas MPA and REF sites during the 2008-2009 field seasons ( $n=121)$. The average $L_{\infty}$ value was $32.50 \mathrm{~cm} \pm 0.95$, and the average $K$ value was $0.22 \pm 0.02$. The value for $t_{0}$ was fixed at -0.5 (Lea et al. 1999). Circles represent data points from the MPA site, and plus symbols represent data points from the REF site. 


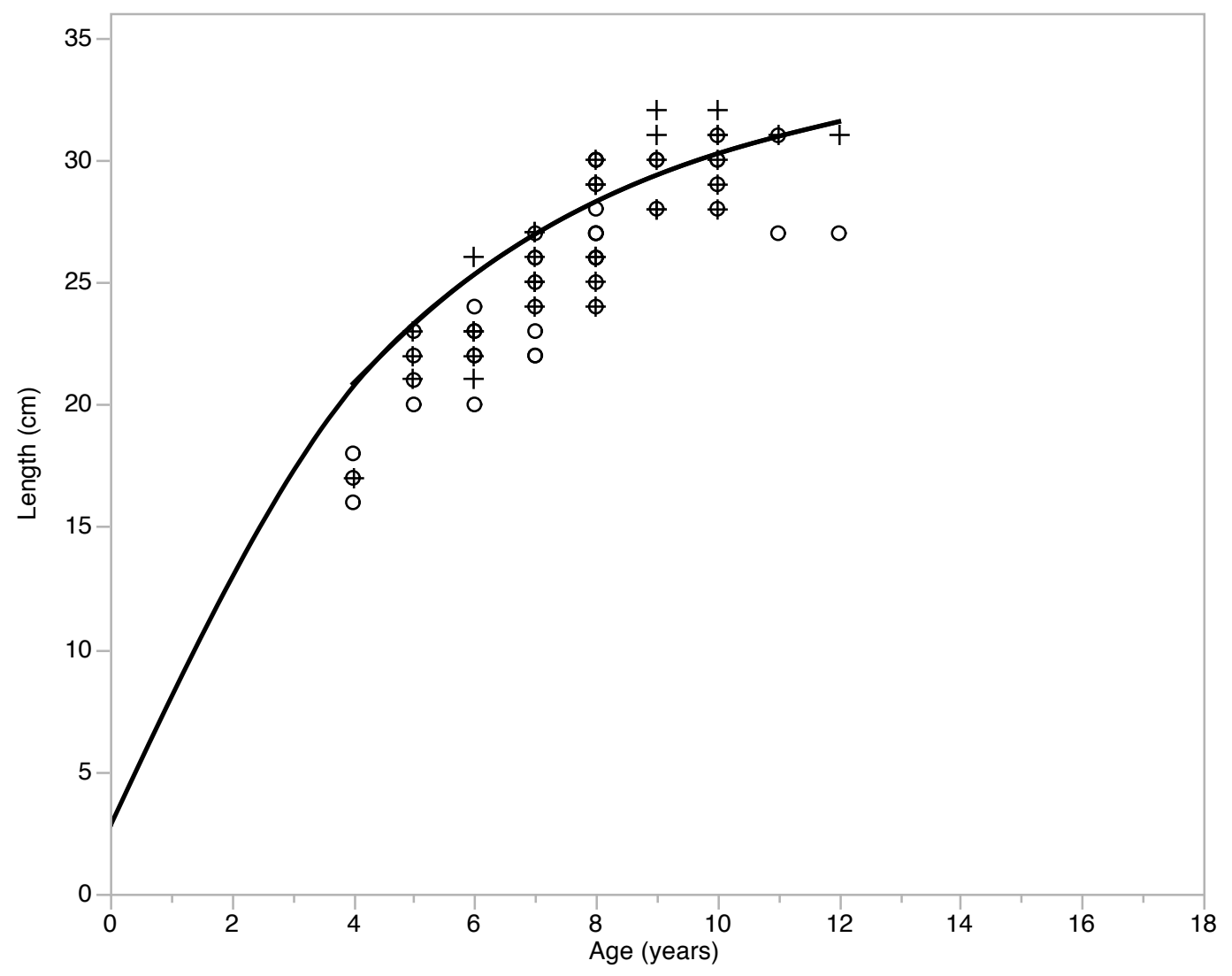

Figure 5. von Bertalanffy growth curve for gopher rockfish sampled in the Piedras Blancas MPA and REF sites during the 2012-2013 field seasons ( $n=$ 86). The average $L_{\infty}$ value was $35.96 \mathrm{~cm} \pm 1.37$, and the average $K$ value was $0.18 \pm 0.01$. The value for $t_{0}$ was fixed at -0.5 (Lea et al. 1999). Circles represent data points from the MPA site, and plus symbols represent data points from the REF site.

\section{MATURITY}

Based on our data, size at $50 \%$ maturity $\left(L_{50}\right)$, the length at which $50 \%$ of gopher rockfish from south central California attain sexual maturity, for individuals sampled from all areas and sites was $23.61 \mathrm{~cm}$ with an approximate $95 \%$ confidence interval from 23.04 to $24.15 \mathrm{~cm}\left(n=194 ; R^{2}=0.74 ; p<\right.$ 
$0.0001)$. Age at $50 \%$ maturity $\left(A_{50}\right)$, for individuals sampled from all areas and sites was 6.01 years with an approximate $95 \%$ confidence interval from 5.72 to 6.29 years $\left(n=194 ; R^{2}=0.60 ; p<0.0001\right)$. By comparing $95 \%$ confidence intervals for the mean size (age) at reproductive maturity between area or site, we found no significant differences. The youngest and smallest mature female recorded was four years old and measured $22 \mathrm{~cm}$. The youngest and smallest mature male recorded was six years old and measured $23 \mathrm{~cm}$. The mean age/length of immature females and males was 5.21 years $/ 20.76 \mathrm{~cm}$ and 5.25 years $/ 21.58 \mathrm{~cm}$, respectively. The mean age/length of mature females and males was 8.71 years $/ 28.79 \mathrm{~cm}$ and 8.39 years $/ 27.77 \mathrm{~cm}$, correspondingly.

\section{CONDITION}

The mean hepatosomatic index for gopher rockfish in south central California was $2.28 \pm 0.06$. Analysis using a two-way ANOVA comparing mean hepatosomatic indices between areas and sites indicate geographic variation between the Piedras Blancas and Point Buchon areas $(p<0.0001)$. Furthermore, mean hepatosomatic index was significantly greater in the Piedras Blancas MPA in comparison to the Point Buchon MPA $(p<0.0001)$. However the mean hepatosomatic indices of fish between sites (MPA and REF) were not significantly different $(p>0.05)$. 


\section{DISCUSSION}

\section{GROWTH PARAMETER ESTIMATES}

We were able to locally define growth parameter values (maximum size and maximum age), size (age) at reproductive maturity, and a measure of condition of gopher rockfish in south central California, which can serve as the basis for comparisons on broader geographic scales and times. Furthermore, we found temporal increases in growth parameters after the establishment of MPAs.

Lea et al. (1999) examined life history traits of nearshore rockfishes, including gopher rockfish, in central California during the 1980's. The majority of samples were collected near Monterey, however the study region spanned from Monterey Bay to Morro Bay. The following growth parameters were estimated for gopher rockfish in central California (sexes combined) for Lea's study: $L_{\infty}=$ $34.1, K=0.23$, and $t_{0}-0.5$. The $K$ and $L_{\infty}$ values from this study are relatively comparable to $K$ and $L_{\infty}$ values from our research.

After addressing our research goal that compared data inside and outside of MPAs, between study areas, as well as between time periods, we found differences in growth parameter values (maximum size and age), likely caused by natural and anthropogenic factors. Differences in growth parameter values imply that MPAs may have influenced the longevity and size of gopher rockfish in both Piedras Blancas and Point Buchon. Our data showed, over time, increases in $L_{\infty}$ and $T_{\max }$ in the Point Buchon MPA compared to the REF sites. When the data from both the MPA and REF sites were combined in Point Buchon, temporal increases in $L_{\infty}$ and $T_{\max }$ were also observed. Relatively recent pre-MPA baseline 
data from the south central coast region show that recreational fishing effort was not as intense in the Piedras Blancas area (MPA and REF sites) when compared to the Point Buchon area (MPA and REF sites) prior to the implementation of MPAs (Ivens-Duran et al. submitted). Past fishing effort in Point Buchon may have preferentially selected larger and older individuals from the population. With the elimination of fishing in the Point Buchon MPA, it appears that gopher rockfish were able to reach older ages and larger sizes. Furthermore, there were no differences found between $L_{\infty}$ estimates for individuals from the Point Buchon MPA and REF sites within separate year classes for a given area. This may be due to fish reaching maximum (asymptotic) lengths, however continuing to age. In addition to this, adult gopher rockfish that normally occupy MPAs may have traveled outside of reserve boundaries (or vice versa) during our sample seasons and were captured during hook-and-line surveys. In the Piedras Blancas MPA, temporal increases in $T_{\max }$ were observed; however, no differences existed between estimates of $L_{\infty}$ over time. Yet when MPA and REF were combined, both $T_{\max }$ and $L_{\infty}$ increased over time. The Piedras Blancas MPA and REF were sampled a year less than the Point Buchon MPA and REF, and perhaps missing data from 2007 is the reason we did not detect temporal differences in estimated $L_{\infty}$ from the MPA site. It has also been shown that a regional shift in fishing effort away from the Piedras Blancas area occurred with the implementation of MPAs in 2007 (Ivens-Duran et al. submitted). This pattern may explain why no differences were observed in either $L_{\infty}$ or $T_{\max }$ between MPA and REF sites. It 
may be that a significant decrease in fishing effort in the area allowed for fish to reach larger sizes and older ages in the Piedras Blancas area as a whole.

Data from gopher rockfish sampled in the Point Buchon and Piedras Blancas areas suggest that six years may be long enough to observe changes in growth parameters of gopher rockfish, due to the removal of fishing pressure. In the past, fishing has altered growth in Atlantic salmon (Ricker 1981), Atlantic cod (Swain et al. 2007) plaice (Rijnsdorp 1993), grayling (Haugen and Vøllestad 2001), and Atlantic silverside (Conover and Munch 2002). Temporal increases in $L_{\infty}$ and $T_{\max }$ present in both the Point Buchon and Piedras Blancas areas, as well as differences in $T_{\max }$ between the Point Buchon MPA and REF sites suggests that past fishing pressure and the implementation of marine reserves may allow fish to attain maximum ages and sizes. In general, our data suggest that there has been increased longevity and maximum length after the establishment of MPAs. Size selective harvest from fishing can cause size (age)-truncations in populations where the oldest and largest individuals are being preferentially removed from populations (Rochet 1998). The elimination of fishing pressure in the Point Buchon and Piedras Blancas MPAs may explain these differences in life history traits, although environmental factors may also be influencing growth parameters. Comparing our data among broader geographic scales and over a longer time frame may provide insight into more suitable management strategies. A next step would be to expand the collection of life history information on gopher rockfish to include the full geographic range of this species. 


\section{MATURITY}

Comparing size (age) at maturity from our research to a past study reveals differences in values. Echeverria 1987 studied reproductive aspects of rockfishes from July 1977-July 1982 in northern and central California (between Port San Luis and Crescent City). Gopher rockfish (sexes combined) age and size at 50\% maturity were calculated as 4 years and $17 \mathrm{~cm}$, respectively (Echeverria 1987). Because our data showed gopher rockfish were maturing two years later and over five centimeters larger sizes, this suggests either a change in maturity over time, between regions, from additional sources (like fishing pressure), or a combination of factors. Delayed maturity and increased lifespans may result from excessive mortality (fishing) of individuals prior to them reaching maturity (Giesel 1976). Furthermore, fishing adults in excess may decrease size and age at maturity (Giesel 1976), which has been shown in Atlantic cod (Beacham 1983; Olsen et al. 2004), Northeast Arctic cod (Jørgenson 1990), plaice (Rijnsdorp 1993), and grayling (Haugen and Vøllestad 2001). While we cannot determine what factor has predominantly contributed to these differences, future management should apply this regional knowledge. Past management decisions that were based on information from the stock assessment may be inappropriate for south central California gopher rockfish, therefore future strategies should reflect current trends. Harvest rates should be calculated based off of this local maturity information. Without running harvest models, delayed maturity can translate to delayed recruitment; therefore, a fish reaching maturity at larger sizes and older ages could indicate a more conservative estimate of reproductive output. If this is 
the case, fish with delayed maturity may require more conservative harvest rates than previously determined from the past stock assessment. It would be beneficial to collect regional data over longer time periods to establish appropriate localized management for this species. Because life history characteristics can vary over time and space, it is essential to utilize accurate regional data for local populations; doing so enables management on a more ecosystem-based spatial scale.

Area, site, and sex were not associated with changes in age or size at maturity, suggesting that past fishing pressure and the subsequent elimination of fishing pressure have not elicited plastic responses in fishes sampled.

\section{CONDITION}

Spatial variation existed in the hepatosomatic indices of fish collected from Piedras Blancas compared to Point Buchon, which can likely be attributed to multiple environmental factors. The relative abundance of predators and predation pressure may impact the condition of prey species. Energy spent avoiding predation may decrease energy reserves (Walsh et al. 2012); likely translating to decreases in hepatosomatic indices. Lingcod, Ophiodon elongatus, is a predatory teleost that often preys on gopher rockfish (Love 2011). Lingcod abundance measured in catch-per-unit-effort (CPUE) is significantly greater $(p<0.0001)$ in the Point Buchon MPA in years 2012-2013 than in the Piedras Blancas MPA in years 2012-2013 (California Collaborative Fisheries Research Program (CCFRP) Annual Report, 2014), which may explain spatial differences in HSI between areas. More lingcod in the Point Buchon MPA could mean greater predation 
pressure, which may alter energy reserves in prey species like gopher rockfish. In addition, food quality and quantity may influence fish condition. Dietary digestible lipid is known to increase hepatosomatic indices in juvenile Korean rockfish, Sebastes schlegeli (Lee et al. 2002). A gut content study by Loury (2011) showed differences in gopher rockfish diet between Piedras Blancas and Point Buchon. Data regarding gopher rockfish diet trends during our study years do not exist; at present it is unknown how temporally stable these patterns in diet are. While the difference in hepatosomatic indices between our study areas is likely due to various environmental factors, it is difficult to interpret our results at this time.

\section{CONCLUSIONS}

Our data suggest that both natural and anthropogenic factors, including the removal of fishing pressure, may explain some spatial and temporal differences in life history traits and condition of gopher rockfish from south central California. The elimination of fishing, after the implementation of the Point Buchon and Piedras Blancas MPAs, may have resulted in increased longevity and maximum sizes of individuals in these reserves. In order to determine if these patterns are temporally stable, this study should be conducted over a longer period of time. Future research should focus on the long-term effects of eliminating fishing on gopher rockfish life history characteristics. While it will be difficult to determine if potential life history changes are due to plastic or adaptive responses, determining the lasting effects of MPA implementation on these parameters is a topic worth further investigating. Moreover, factors like predation pressure and 
diet are possible explanations for variation in fish condition between study areas. Environmental information should be monitored to verify influences on body condition. Localized life history information expanding over the full range of this species could theoretically help policymakers better manage gopher rockfish stocks at smaller regional levels. Overall, it is essential to gather current life history and condition data to understand spatial and temporal differences of an economically valuable species in order to manage stocks sustainably for the future. 


\section{REFERENCES}

Adams, P. B. 1980. Life history patterns in marine fishes and their consequences for fisheries management. Fishery Bulletin. 78: 1-12.

Beacham, T. D. 1983. Variability in median size and age at sexual maturity of Atlantic cod (Gadus morhua) on the Scotian shelf in the Northwest Atlantic Ocean. Fisheries Bulletin. 181(2): 303-321.

Berkeley, S. A., C. Chapman, and S. M. Sogard. 2004. Maternal age as a determinant of larval growth and survival in a marine fish, Sebastes melanops. Ecology. 85(5): 1258-1264.

Beverton, R. J. H. 1992. Patterns of reproductive strategy parameters in some marine teleost fishes. Journal of Fish Biology. 41(sB): 137-160.

Bolger, T. and P. L. Connolly. 1989. The selection of suitable indices for the measurement and analysis of fish condition. Journal of Fish Biology. 34(2): 171-182.

California Collaborative Fisheries Research Program (CCFRP). (2014). 2013 Annual Report. Retrieved from http://seagrant.mlml.calstate.edu/.

Caselle, J. E., S. L. Hamilton, D. M. Schroeder, M. S. Love, J. D. Standish, J. A. Rosales-Casian, and O. Sosa-Nishizaki. 2011. Geographic variation in density, demography, and life history traits of a harvested, sex-changing, temperate reef fish. Canadian Journal of Fisheries and Aquatic Sciences. 68(2): 288-303.

Chen, C., L.Weiss, R. Barger, T. Hesselgrave, C. Steinback, J.Bonkoski, K. Sheeran, N. Lyman, J. Bloeser, and D. Aseltine-Neilson. 2012. Assessing 
Spatial and Socioeconomic Change in the California Central Coast

Commercial and CPFV Fisheries. Report to the MPA Monitoring

Enterprise, California Ocean Science Trust.

Chilton, E. 2007. Maturity of female Northern Rockfish Sebastes polyspinis in the central Gulf of Alaska. Alaska Fishery Research Bulletin.12: 264-269.

Conover, D. O., and S. B. Munch. 2002. Sustaining fisheries yields over evolutionary time scales. Science. 297(5578): 94-96.

Conover, D. O. 2007. Fisheries: nets versus nature. Nature. 450(7167): 179-180.

Echeverria, T. W. 1987. Thirty-four species of California rockfishes: Maturity and seasonality of reproduction. Fishery Bulletin. 85(2): 229-250.

Giesel, J.T. 1976. Reproductive strategies as adaptations to life in temporally heterogeneous environments. Ann. Rev. Ecol. Syst. 7: 57-79.

Haugen, T. O., and L. A. Vøllestad. 2001. A century of life-history evolution in grayling. Microevolution Rate, Pattern, Process: Springer Netherlands. 8: 475-491.

Hixon, M. A., D. W. Johnson, and S. M. Sogard. 2013. BOFFFFs: on the importance of conserving old-growth age structure in fishery populations. ICES Journal of Marine Science: Journal du Conseil, fst200.

Ivens-Duran, M. 2014. submitted.

Jordan, D.S., and Gilbert, C.H. 1880. Description of seven new species of sebastoid fishes, from the coast of California. Proc. U.S. Natl. Mus. 3: $287-298$.

Jørgensen, T. 1990. Long-term changes in age at sexual maturity of Northeast 
Arctic cod (Gadus morhua). Journal du Conseil International pour l'Exploration de la Mer. 46: 235-248.

Karpov, K. A., D. P. Albin, and W. H. Van Buskirk. 1995. The marine recreational fishery in northern and central California. California Department of Fish and Game, Fish Bulletin. 176: 195.

Key, M., A. D., MacCall, T. Bishop, and B. Leos. 2005. Stock assessment of the gopher rockfish (Sebastes carnatus). California Department of Fish and Game.

Lambert, Y., and Dutil, J.-D. 1997. Can simple condition indices be used to monitor and quantify seasonal changes in the energy re- serves of Atlantic cod (Gadus morhua)? Can. J. Fish. Aquat. Sci. 54(Suppl. 1): 104-112.

Law, R. 2000. Fishing, selection, and phenotypic evolution. ICES Journal of Marine Science: Journal du Conseil. 57(3): 659-668.

Lea, R. N, R. D. McAllister, and D. A. VenTresca. 1999. Biological Aspects of Nearshore Rockfishes of the Genus Sebastes from Central California With Notes On Ecologically Related Sport Fishes. Fish Bulletin. 177.

Leaman, B. M. 1991. Reproductive styles and life history variables relative to exploitation and management of Sebastes stocks. Environmental Biology of Fishes. 30:253-271.

Lee, S. M., I. G. Jeon, and J. Y. Lee. 2002. Effects of digestible protein and lipid levels in practical diets on growth, protein utilization and body composition of juvenile rockfish (Sebastes schlegeli). Aquaculture. 211(1): 227-239. 
Loury, E. K. 2011. Diet of the Gopher Rockfish (Sebastes carnatus) Inside and Outside of Marine Protected Areas in Central California.

Love, M. S., J. E. Caselle, and W. H. Van Buskirk. 1998. A severe decline in the commercial passenger fishing vessel rockfish (Sebastes spp.) catch in the Southern California Bight, 1980-1996. Calif. Coop. Ocean. Fish. Investig. Rep. 39:180-195.

Love, M. S., M. Yoklavich, and L. Thorsteinson. 2002. The rockfishes of the Northeast Pacific. University of California Press, Berkley. 405.

Love, M. S. 2011. Certainly More Than You Want to Know About the Fishes of the Pacific Coast. Really Big Press. Santa Barbara, California.

Mason, J. E. 1998. Declining rockfish lengths in the Monterey Bay, California, recreational fishery, 1959-94. Marine Fisheries Review. 60(3): 15-28.

O'Farrell, M. R. and L. W. Botsford. 2005. Estimation of change in lifetime egg production from length frequency data. Canadian Journal of Fisheries and Aquatic Sciences. 62(7): 1626-1639.

Olsen E. M, M. Heino, G. R. Lilly, M. J. Morgan, J. Brattey, B. Ernande, U. Dieckmann. 2004. Maturation trends indicative of rapid evolution preceded the collapse of northern cod. Nature. 428: 932-935.

Palumbi, S. R. 2004. Fisheries science: Why mothers matter. Nature. 430(7000): 621-622.

Parker, S. J., S. A. Berkeley, J. T. Golden, D. R. Gunderson, J. Heifetz, M. A. Hixon, R. Larson, B. M. Leaman, M. S. Love, J. A. Musick, V. M. O’Connell, S. Ralston, H. J. Weeks, and M. M. Yoklavich. 2000. 
Management of Pacific rockfish. Fisheries. 25(3): 22-30.

Rätz, H. J. and J. Lloret. 2003. Variation in fish condition between Atlantic cod (Gadus morhua) stocks, the effect on their productivity and management implications. Fisheries Research. 60(2): 369-380.

Reynolds, J. D., N. K. Dulvy, N. B. Goodwin, and J. A. Hutchings. 2005. Biology of extinction risk in marine fishes. Proceedings of the Royal Society B: Biological Sciences. 272(1579): 2337-2344.

Reznick, D. A., H. Bryga, and J. A. Endler. 1990. Experimentally induced lifehistory evolution in a natural population. Nature. 346: 357-359.

Ricker, W. E. 1981. Changes in the average size and average age of Pacific salmon. Canadian Journal of Fisheries and Aquatic Sciences. 38(12): 1636-1656.

Rijnsdorp, A. D. 1993. Fisheries as a large-scale experiment on life-history evolution: disentangling phenotypic and genetic effects in changes in maturation and reproduction of North Sea plaice, Pleuronectes platessa L. Oecologia. 96(3): 391-401.

Rochet, M. J. 1998. Short-term effects of fishing on life history traits of fishes. ICES Journal of Marine Science: Journal du Conseil. 55(3): 371-391.

Roff, D. A. 1984. The evolution of life history parameters in teleosts. Canadian Journal of Fisheries and Aquatic Sciences. 41: 898-1000.

Ruttenberg, B. I., A. J. Haupt, A. I. Chiriboga, and R. R. Warner. 2005. Patterns, causes and consequences of regional variation in the ecology and life history of a reef fish. Oecologia. 145(3): 394-403. 
Sogard, S. M., S. A. Berkeley, and R. Fisher. 2008. Maternal effects in rockfishes Sebastes spp.: a comparison among species. MARINE ECOLOGYPROGRESS SERIES. 360: 227.

Stokes, T. K., J. M. McGlade, and R. Law (Eds). 1993. The Exploitation of Evolving Resources. Berlin: Springer-Verlag.

Swain, D. P., A. F. Sinclair, and J. M. Hanson. 2007. Evolutionary response to size-selective mortality in an exploited fish population. Proceedings of the Royal Society B: Biological Sciences. 274(1613): 1015-1022.

TenBrink, T. T., and P. D. Spencer. 2013. Reproductive Biology of Pacific Ocean Perch and Northern Rockfish in the Aleutian Islands. North American Journal of Fisheries Management. 33(2): 373-383.

von Bertalanffy, L. 1934. Untersuchungen fiber die Gesetzlichkeit des Wachstums. I. Allgemeine Grundlagen der Theorie mathematische und physiologische Gesetzlichkeiten des Wachstums bei Wassertieren. Roux Arch. Entwicklungsmech. 131: 613-652.

Walsh, S. M., S. L. Hamilton, and B. I. Ruttenberg. Donovan, M. K., and Sandin, S. A. 2012. Fishing top predators indirectly affects condition and reproduction in a reef-fish community. Journal of fish biology. 80(3): 519537.

Wendt D. E. and R. M. Starr. 2009. Collaborative Research: An Effective Way to Collect Data for Stock Assessments and Evaluate Marine Protected Areas in California. Marine and Coastal Fisheries: Dynamics, Management, and Ecosystem Science. 1:315-324. 